\title{
Quinoa (Chenopodium quinoa Willd.) as a source of nutrients and bioactive compounds: a review
}

\author{
Blanca Hernández-Ledesma*
}

Instituto de Investigación en Ciencias de la Alimentación, CIAL (CSIC-UAM, CEI UAM+CSIC), Nicolás Cabrera, 9, 28049 Madrid, Spain

Submission date: September $12^{\text {th }}, 2018$, Acceptance Date: March $28^{\text {th }}$, 2019, Publication Date: March $31^{\text {st }}, 2019$

Corresponding Author: Blanca Hernández-Ledesma, Instituto de Investigación en Ciencias de la Alimentación, CIAL (CSIC-UAM, CEI UAM+CSIC), Nicolás Cabrera, 9, 28049 Madrid, Spain

Citation: Hernández-Ledesma B. Quinoa (Chenopodium quinoa Willd.) as a source of nutrients and bioactive compounds: a review. Bioactive Compounds in Health and Disease 2019; 2(3):2747. DOI: https://doi.org/10.31989/bchd.v2i3.556

\begin{abstract}
Quinoa (Chenopodium quinoa Willd.) is a pseudocereal traditionally cultivated by Andean cultures which production and consumption has increased worldwide in the last decades. Quinoa was defined as "one of the grains of the $21^{\text {st }}$ century" because of its resistance to extreme environmental conditions and its nutritional and functional properties. In addition to its high content in protein, lipids, fiber, vitamins, and minerals, and its excellent balance of essential amino acids, quinoa contains a plethora of phytochemicals including saponins, phytosterols, phytoecdysteroids, phenolic compounds, polysaccharides, and bioactive proteins and peptides. The recent investigations demonstrating the beneficial effects of these compounds on metabolic, cardiovascular, and gastrointestinal health have made quinoa to gain recognition as a functional food and nutraceutical. This review summarizes the available data on the nutritional and functional role of quinoa emphasizing the bioactive compounds mainly responsible for the health benefits attributed to this crop.
\end{abstract}

Keywords: quinoa, pseudocereal, nutritional value, bioactive compounds, health benefits

Submission date: December $3^{\text {rd }}$, 2018, Acceptance Date: March 28 ${ }^{\text {th }}$, 2019, Publication Date: March 31 $1^{\text {st }}, 2019$

\section{General aspects}

The genus Chenopodium (family Chenopodiaceae) is distributed worldwide and includes 250 species with a great diversity in plants and inflorescences. Cultivated and collected 
Chenopodium species have been part of the pre-Columbian (Tiahuanacotan and Incan) cultures. Chenopodium quinoa is tetraploid specie, similar to beets and amaranth. Originated in the Andean region of Bolivia and Peru, quinoa has been cultivated in these areas for the last 50 centuries [1]. For the Incas, quinoa was a very important crop together with corn and potato. In addition to its role in human and animal nutrition, quinoa had a sacred value as a gift from the gods [2]. It is known with different local names such as supha, suba, jupha, and dahue although it is called quinoa or quinua in Bolivia, Peru, Ecuador, Argentina and Chile where is mainly grown.

The plant is able to tolerate extreme environmental conditions (salinity, cold, solar radiation, and drought), and it can be cultivated in high altitudes in the mountain areas where it is not possible to grow maize. Its genetic variability is great, with cultivars of quinoa being adapted to growth in a wide range of environments from $20^{\circ}$ latitude North in Colombia to $40^{\circ}$ latitude South in Chile, and from sea level to an altitude of 3,800 m [3]. The high adaptability of this crop to diverse agro-climatic habitats and edaphic conditions has increased the yields of diverse varieties in countries outside South America, such as USA, Canada, Europe, India, and China [4, 5]. Thus, the world production of quinoa has augmented in the last years and was close to 150,000 tonnes in 2016 (Figure 1) [6].

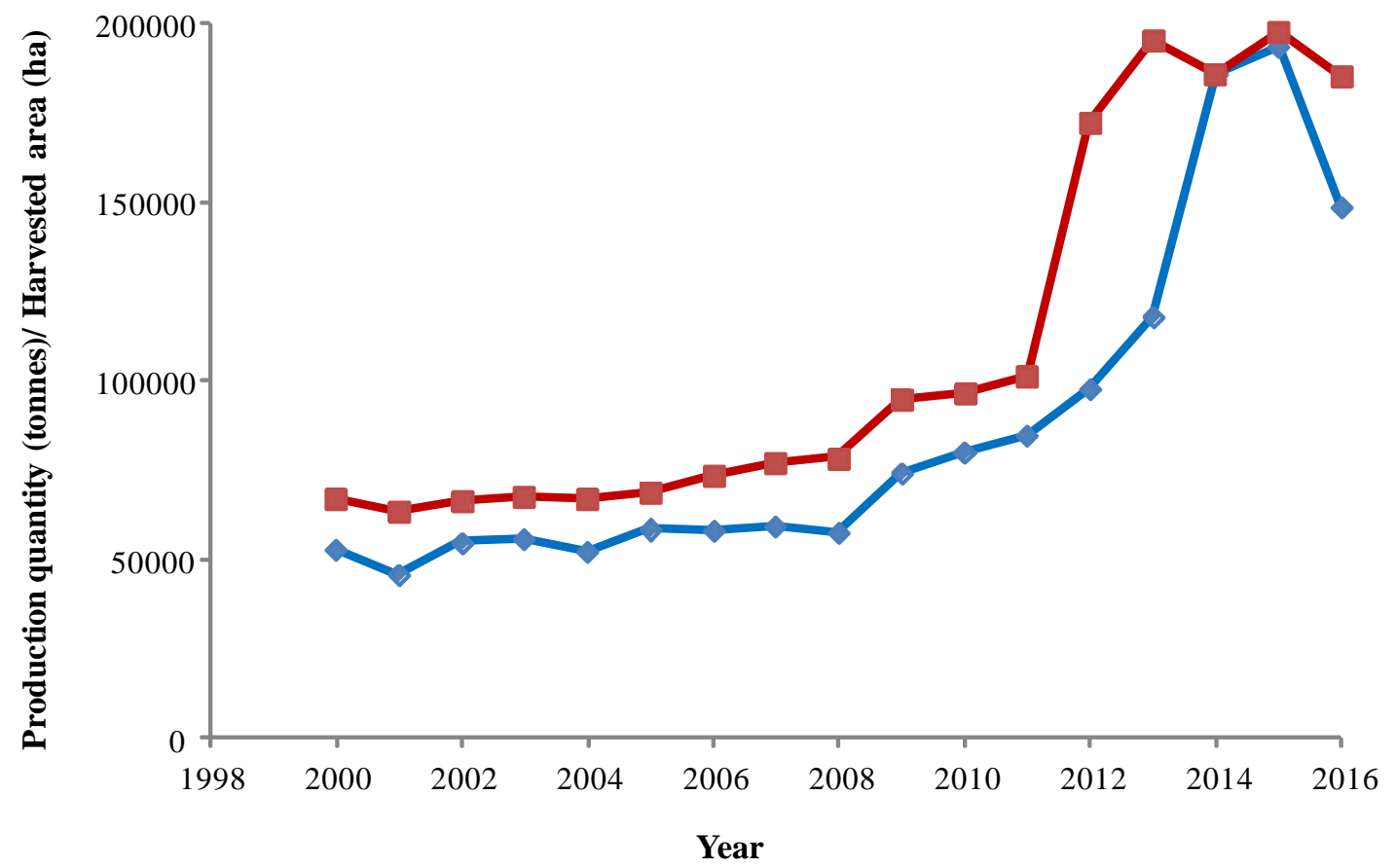

Figure 1. World production quantity (in tonnes, blue rombus) and harvested area (in ha, red square) of quinoa from 2000 to 2016 (FAOSTAT 2018).

This plant is considered as pseudocereal as it does not belong to the Gramineae family although it has the characteristics of grains. It produces seeds that can be milled into flour and used as a cereal crop. A number of toasted and baked goods are produced from quinoa flour, such as bread, cookies, biscuits, noodles, pasta, tortilla, and pancakes [7]. Moreover, quinoa seeds can be fermented to make beer and "chicha", a ceremonial alcoholic beverage from South America [8]. Quinoa leaves are similarly consumed as spinach [9], and the germinated seedlings 
(sprouts) are added to salads [10]. Also, the whole plant has been also used as a rich nutritional source to feed livestock, including cattle, pigs, and poultry [7].

Because of its stress-tolerant characteristics and its nutritional and biological properties, quinoa has been described as "one of the grains of the $21^{\text {st }}$ century" [10]. In 2013, the Food and Agriculture Organization of the United Nations (FAO) launched the International Year of Quinoa to promote the planting, production, preservation, consumption, and research on this plant [11]. Moreover, recent investigations focused on the chemical constituents and therapeutic properties of quinoa have made it to gain recognition as a functional food and nutraceutical [12]. This review presents a summary of the available literature on the nutritional and biological properties of quinoa seed emphasizing on the bioactive compounds which are mainly responsible for the health benefits attributed to this crop.

\section{Nutritional quality of quinoa}

Table 1 shows a comparison of the nutritional values of quinoa in relation to durum wheat, white rice (medium-grain, raw, un-enriched), and yellow corn grain, considered as some of the most crucial foods worldwide in both human and animal diets [13].

Table 1. Approximate chemical composition of quinoa (uncooked) compared to wheat (durum), white rice (medium-grain, raw, un-enriched), and yellow corn grain. Data obtained from USDA (2018)

\begin{tabular}{|c|c|c|c|c|}
\hline Nutrient & Quinoa & Durum wheat & White rice & $\begin{array}{c}\text { Yellow corn } \\
\text { grain }\end{array}$ \\
\hline Water $^{\mathrm{a}}$ & 13.3 & 10.9 & 12.9 & 10.4 \\
\hline Energy (Kcal) & 368.0 & 339.0 & 360.0 & 365.0 \\
\hline Total protein ${ }^{\mathrm{a}}$ & 14.1 & 13.7 & 6.6 & 9.4 \\
\hline Total fat ${ }^{\mathrm{a}}$ & 6.1 & 2.5 & 0.6 & 4.7 \\
\hline Carbohydrates $^{\mathrm{a}}$ & 64.2 & 71.1 & 79.3 & 74.3 \\
\hline Dietary Fiber ${ }^{\mathrm{a}}$ & 7.0 & n.r. & n.r. & 7.3 \\
\hline $\mathrm{Ash}^{\mathrm{a}}$ & 2.4 & 1.8 & 0.6 & 1.2 \\
\hline \multicolumn{5}{|l|}{ Minerals } \\
\hline Calcium $^{\mathrm{b}}$ & 47.0 & 34.0 & 9.0 & 7.0 \\
\hline Iron $^{\mathrm{b}}$ & 4.6 & 3.5 & 0.8 & 2.7 \\
\hline Magnesium ${ }^{\mathrm{b}}$ & 197.0 & 144.0 & 35.0 & 127.0 \\
\hline Phosphorus ${ }^{\mathrm{b}}$ & 457.0 & 508.0 & 108.0 & 210.0 \\
\hline Potassium $^{\mathrm{b}}$ & 563.0 & 431.0 & 86.0 & 287.0 \\
\hline Sodium $^{\mathrm{b}}$ & 5.0 & 2.0 & 1.0 & 35.0 \\
\hline Zinc $^{\mathrm{b}}$ & 3.1 & 4.2 & 1.2 & 2.2 \\
\hline Copper $^{\mathrm{b}}$ & 0.6 & 0.6 & 0.1 & 0.3 \\
\hline Manganese ${ }^{b}$ & 2.0 & 3.0 & 1.1 & 0.5 \\
\hline Selenium ${ }^{\mathrm{c}}$ & 8.5 & 89.4 & ND & 15.5 \\
\hline \multicolumn{5}{|l|}{ Vitamins } \\
\hline Vitamin $C^{c}$ & n.r. & 0.0 & 0.0 & 0.0 \\
\hline Thiamin $\left(\mathrm{B}_{1}\right)^{\mathrm{b}}$ & 0.36 & 0.42 & 0.07 & 0.39 \\
\hline Riboflavin $\left(\mathrm{B}_{2}\right)^{\mathrm{b}}$ & 0.32 & 0.12 & 0.05 & 0.20 \\
\hline Niacin $\left(B_{3}\right)^{\mathrm{b}}$ & 1.52 & 6.74 & 1.6 & 3.63 \\
\hline Pantothenic acid ${ }^{b}$ & 0.77 & 0.94 & 1.34 & n.r. \\
\hline Pyridoxine $\left(\mathrm{B}_{6}\right)^{\mathrm{b}}$ & 0.49 & 0.42 & 0.15 & 0.62 \\
\hline
\end{tabular}




\begin{tabular}{|c|c|c|c|c|}
\hline Nutrient & Quinoa & Durum wheat & White rice & $\begin{array}{l}\text { Yellow corn } \\
\text { grain }\end{array}$ \\
\hline Folate $^{c}$ & 184 & 43.0 & 9.0 & 19.0 \\
\hline Folic acid ${ }^{c}$ & 0.0 & 0.0 & 0.0 & 0.0 \\
\hline Choline total $^{\mathrm{b}}$ & 70.2 & n.r. & n.r. & n.r. \\
\hline Betaine $^{b}$ & 630.4 & n.r & n.r. & n.r. \\
\hline Vitamin $B_{12}{ }^{c}$ & 0.0 & 0.0 & n.r. & n.r. \\
\hline Vitamin $A^{c}$ & 1.0 & 0.0 & n.r. & 11.0 \\
\hline$\beta$-carotene $e^{c}$ & 8.0 & n.r. & n.r. & n.r. \\
\hline$\alpha$-carotene $e^{c}$ & 0.0 & n.r. & n.r. & n.r. \\
\hline$\beta$-cryptoxanthin ${ }^{\mathrm{c}}$ & 1.0 & n.r. & n.r. & n.r. \\
\hline Lycopene $^{c}$ & 0.0 & n.r. & n.r. & n.r. \\
\hline Lutein + Zeaxanthin ${ }^{c}$ & 163.0 & n.r. & n.r. & n.r. \\
\hline$\alpha$-tocopherol $(\mathrm{E})^{\mathrm{b}}$ & 2.44 & n.r. & n.r. & 0.49 \\
\hline$\beta$-tocopherol ${ }^{\mathrm{b}}$ & 0.08 & n.r. & n.r. & n.r. \\
\hline$\gamma$-tocopherol ${ }^{\mathrm{b}}$ & 4.55 & n.r. & n.r. & n.r. \\
\hline$\delta$-tocopherol ${ }^{\mathrm{b}}$ & 0.35 & n.r. & n.r. & n.r. \\
\hline Vitamin $\mathrm{D}\left(\mathrm{D}_{2}+\mathrm{D}_{3}\right)^{\mathrm{c}}$ & 0.0 & 0.0 & 0.0 & 0.0 \\
\hline Vitamin $\mathrm{K}^{\mathrm{c}}$ & 0.0 & n.r. & n.r. & 0.3 \\
\hline \multicolumn{5}{|l|}{ Lipids } \\
\hline Fatty acids, $\mathrm{SFA}^{\mathrm{a}}$ & 0.71 & 0.45 & 0.16 & 0.67 \\
\hline Fatty acids, $\mathrm{MFA}^{\mathrm{a}}$ & 1.61 & 0.34 & 0.18 & 1.25 \\
\hline Fatty acids, $\mathrm{PFA}^{\mathrm{a}}$ & 3.29 & 0.98 & 0.16 & 2.16 \\
\hline \multicolumn{5}{|l|}{ Essential amino acids } \\
\hline $\operatorname{Trp}^{\mathrm{a}}$ & 0.17 & 0.18 & 0.08 & 0.07 \\
\hline $\mathrm{Thr}^{\mathrm{a}}$ & 0.42 & 0.37 & 0.24 & 0.35 \\
\hline $\mathrm{Ile}^{\mathrm{a}}$ & 0.50 & 0.53 & 0.29 & 0.34 \\
\hline Leu $^{\mathrm{a}}$ & 0.84 & 0.93 & 0.55 & 1.16 \\
\hline Lys $^{a}$ & 0.77 & 0.30 & 0.24 & 0.27 \\
\hline $\mathrm{Met}^{\mathrm{a}}$ & 0.31 & 0.22 & 0.16 & 0.20 \\
\hline $\mathrm{Cys}^{\mathrm{a}}$ & 0.20 & 0.29 & 0.14 & 0.17 \\
\hline $\mathrm{Phe}^{\mathrm{a}}$ & 0.59 & 0.68 & 0.35 & 0.46 \\
\hline Tyr $^{\mathrm{a}}$ & 0.27 & 0.36 & 0.22 & 0.38 \\
\hline $\mathrm{Val}^{\mathrm{a}}$ & 0.59 & 0.59 & 0.40 & 0.48 \\
\hline $\operatorname{Arg}$ & 1.09 & 0.48 & 0.55 & 0.47 \\
\hline $\mathrm{His}^{\mathrm{a}}$ & 0.41 & 0.32 & 0.16 & 0.29 \\
\hline $\mathrm{Ala}^{\mathrm{a}}$ & 0.59 & 0.43 & 0.38 & 0.71 \\
\hline Asp $^{a}$ & 1.13 & 0.62 & 0.62 & 0.66 \\
\hline Glu $^{\mathrm{a}}$ & 1.87 & 4.74 & 1.29 & 1.77 \\
\hline Gly $^{\mathrm{a}}$ & 0.69 & 0.50 & 0.30 & 0.39 \\
\hline Pro $^{a}$ & 0.77 & 1.46 & 0.31 & 0.82 \\
\hline $\mathrm{Ser}^{\mathrm{a}}$ & 0.57 & 0.67 & 0.35 & 0.45 \\
\hline
\end{tabular}

${ }^{\mathrm{a}} \mathrm{g} / 100 \mathrm{~g}$ edible portion

${ }^{\mathrm{b}} \mathrm{mg} / 100 \mathrm{~g}$ edible portion

${ }^{c} \mu \mathrm{g} / 100 \mathrm{~g}$ edible portion

n.r.: not reported

SFA: saturated fatty acids

MFA: monounsaturated fatty acids

PFA: polyunsaturated fatty acids

Quinoa's superiority over these and other grains results from its richer protein, lipid, and ash content. According to the USDA Food Composition database, the protein content of quinoa 
seeds is $14.1 \%$, although a range from $13.8-16.5 \%$ protein has been reported [14]. The major storage proteins of quinoa are albumins (35\%) and globulins (37\%), while the prolamins are present in low concentrations [15]. The protein fraction of type $2 \mathrm{~S}$ albumins presents a heterogeneous group of polypeptides with a molecular mass of 8-9 $\mathrm{kDa}$ under reducing conditions. The globulin 11S, called chenopodin, is a $320 \mathrm{kDa}$ oligomeric protein composed by monomers or subunits, which consist of an acid (30-40 kDa) and a basic polypeptide (20-25 $\mathrm{kDa}$ ), linked by disulfide bonds. Chenopodin has become a reference source of leucine, isoleucine, phenylalanine, and tyrosine by the FAO [15].

The nutritional quality of the protein is determined by the proportion of essential amino acids, namely those that must be supplied in the diet because they cannot be synthesized by animals. Quinoa is one of the few plant foods that provide all essential amino acids with an adequate balance for human life. According to FAO/WHO recommendations, quinoa protein can supply over $180 \%$ of the daily recommended intake of essential amino acids for adult nutrition [16]. Specifically, quinoa proteins are high in lysine (ranged from 2.4 to $7.8 \mathrm{~g} / 100 \mathrm{~g}$ protein), methionine (0.3-9.1 g/100 g protein), and threonine (2.1-8.9 g/ $100 \mathrm{~g}$ protein) that are the limiting amino acids in conventional cereals, such as wheat and maize [17].

The protein quality also depends on the digestibility of protein, the influence of antinutritional factors, and the ratio between tryptophan and neutral amino acids [18]. In animal feeding assays, quinoa proteins have shown high digestibility, and thus, $91.6 \%$ of proteins from raw seeds were absorbable, increasing up to $95.3 \%$ after heat treatment (cooking) [19]. The high protein's bioavailability is partially due to the relatively low content of trypsin inhibitors in quinoa seeds which reduce protein enzymatic digestion and absorption [11].

The carbohydrate content of quinoa seed is slightly lower than that of wheat, rice and maize (Table 1). Starch is the major component, comprising 58-1\%-64.2\% of the dry weight [20]. The content of total dietary fiber in quinoa seeds ranges from 7-10\% [13, 21]. Although this content is similar to that present in cereals, its monosaccharide subunit composition is more comparable to that of fruits, vegetables, and legumes. Insoluble quinoa fiber represents $78 \%$ of total fiber content and is constituted mainly by galacturonic acid, arabinose, galactose, xylose, and glucose. Soluble quinoa fiber corresponds to $22 \%$ of total fiber and comprises glucose, galacturonic acid, and arabinose. The grains of quinoa also contain free disaccharides such as sucrose $(2.90 \mathrm{~g} / 100 \mathrm{~g}$ dry weight) and maltose $(1.40 \mathrm{~g} / 100 \mathrm{~g}$ dry weight), and monosaccharides such as glucose (1.70 $\mathrm{g} / 100 \mathrm{~g}$ dry weight) and fructose $(0.20 \mathrm{~g} / 100 \mathrm{~g}$ dry weight $)$ [20].

Besides its high content of protein with good biological quality, quinoa seed has an interesting lipid composition of $6.1 \mathrm{~g} / 100 \mathrm{~g}$ edible portion (Table 1), higher than durum wheat ( $2.5 \mathrm{~g} / 100 \mathrm{~g}$ edible matter), white rice $(0.6 \mathrm{~g} / 100 \mathrm{~g}$ edible matter), and yellow corn grain (4.7 $\mathrm{g} / 100 \mathrm{~g}$ portion), making quinoa be considered as an alternative oilseed crop [14]. Triglycerides and diglycerides are the major fractions present, accounting for over $50 \%$ and $20 \%$, respectively, of the neutral lipids of quinoa seeds [22]. Lysophosphatidyl ethanolamine and phosphatidyl choline are the most abundant (57\%) of the total polar lipids. Quinoa fatty acids are mainly monounsaturated (27\%) and polyunsaturated (55\%), while saturated fatty acids represent $12 \%$ of the total fatty acids (Table 1). The total unsaturated fatty acids content of quinoa (82\%) seeds is similar to that present in yellow corn grain $(73 \%)$ and 1.5- and 1.4-times higher than that present 
in durum wheat and white rice, respectively. The major unsaturated fatty acids in quinoa are linoleic acid (50\%), oleic acid (23\%), and alpha-linolenic acid (5\%), similar to the soybean oil composition [20, 23].

Quinoa is also rich in micronutrients, such as vitamins and minerals (Table 1). Although there is limited research on the vitamin content of quinoa seeds, it is known that it contains vitamin A precursor $\beta$-carotene $(8.0 \mu \mathrm{g} / 100 \mathrm{~g})$, thiamin/vitamin $\mathrm{B}_{1}(0.36 \mathrm{mg} / 100 \mathrm{~g})$, riboflavin/vitamin $\mathrm{B}_{2}(0.32 \mathrm{mg} / 100 \mathrm{~g})$, niacin/vitamin $\mathrm{B}_{3}(1.52 \mathrm{mg} / 100 \mathrm{~g})$, panthothenic $\mathrm{acid} /$ vitamin $\mathrm{B}_{5}(0.77 \mathrm{mg} / 100 \mathrm{~g})$, pyridoxine/vitamin $\mathrm{B}_{6}(0.49 \mathrm{mg} / 100 \mathrm{~g})$, and total folate $(184$ $\mu \mathrm{g} / 100 \mathrm{~g})$ [13]. The contents in $100 \mathrm{~g}$ of pyridoxine $\left(\mathrm{B}_{6}\right)$ and folic acid can meet the needs of children and adults while the content of riboflavin $\left(\mathrm{B}_{2}\right)$ contributes $80 \%$ of the daily needs of children and $40 \%$ that of adults, as cited by Abugoch James [15]. The values of riboflavin $\left(\mathrm{B}_{2}\right)$, pyridoxine $\left(\mathrm{B}_{6}\right)$, and folic acid are higher than those found in most cereals such as wheat, oat, barley, rye, rice, and maize, while that of thiamine $\left(\mathrm{B}_{1}\right)$ is lower than those contained in oats or barley. Moreover, quinoa is an excellent source of vitamin E $(\approx 7.4 \mathrm{mg} / 100 \mathrm{~g}$ edible portion) than can protect fatty acids of cell membranes against oxidative damage [15, 24]. The range of reported ascorbic acid levels is very wide, from 0 to $63.0 \mathrm{mg} / 100 \mathrm{~g}$ dry weight, because of the high susceptibility of this vitamin to oxidation that can misrepresent the results. Quinoa also contains a great concentration of betaine $(630.4 \mathrm{mg} / 100 \mathrm{~g}$ dry portion) and its metabolic precursor choline $(70.2 \mathrm{mg} / 100 \mathrm{~g}$ dry portion). Betaine has been found to contribute to overall health management and to prevent chronic diseases associated to low levels of plasma homocysteine [25]. Choline is a vitamin-like nutrient involved in the synthesis of phospholipids phosphatidylcholine and sphingomyelin that are essential for cell membrane functions [26]. Although these two compounds are not essential, they cannot be synthesized in adequate quantities by the human body, thus they are obtained from foods rich in betaine and choline or by oral supplements with pure preparations [27]. Of commonly consumed foods, refined and whole grain wheat are the best sources of betaine [28]. The high content of betaine and choline found in quinoa has made its incorporation into gluten-free products a good alternative to improve dietary intake of these compounds among people adhering to gluten-free diets [29].

Quinoa has higher total mineral (ash) content (2.4\%, USDA, 2018) than durum wheat $(1.8 \%)$, white rice $(0.6 \%)$, yellow corn grain $(1.2 \%)$, and other cereals [7, 13]. Thus, quinoa grain contains large quantities of minerals, mainly potassium (0.01-1200 g/100 g edible matter), phosphorus (140-530 g/100 g edible portion), magnesium (26.0-502.0 g/100 g), and calcium $(27.5-148.7 \mathrm{~g} / 100 \mathrm{~g})$. Other minerals present in quinoa are iron (1.4-6.8 g/100 g), zinc (2.8-4.8 $\mathrm{g} / 100 \mathrm{~g})$, and copper $(0.2-5.1 \mathrm{~g} / 100 \mathrm{~g})$ [7, 11, 13, 20]. The wide variation among values obtained for each mineral may be related to the fact that the samples belong to different genotypes and were grown in regions with varying soil types and different mineral compositions and/or applied fertilizers. Many of these minerals are present in higher concentrations than those found in common grains. Moreover, calcium, magnesium, and potassium are found in quinoa in bioavailable forms, thus their contents are considered to be adequate for a balanced diet [11, 20]. According to the National Academy of Sciences [30], the magnesium, manganese, copper, and iron present in $100 \mathrm{~g}$ of quinoa seed cover the daily needs of infants and adults, while the 
phosphorus and zinc content is enough for children, but covers $40-60 \%$ of the daily requirements of adults. The potassium content can cover $18 \%$ and $22 \%$ of infant and adult needs, respectively, while the calcium content can meet $10 \%$ of the requirements.

\section{Bioactive compounds in quinoa}

In addition to its high nutritional value and gluten-free nature, quinoa exerts beneficial effects on high-risk group consumers, such as children, the elderly, lactose intolerant, and people with diabetes, obesity, dyslipidemia, anemia, and celiac disease. These effects have been associated with its content of protein, fiber, vitamins and minerals, fatty acids, and especially with the presence of different phytochemicals that provide quinoa a noteworthy advantage over other grains in terms of human nutrition and health [14]. Here, the effects of quinoa bioactive compounds and the evidence on their impact on human health will be summarized.

\section{Saponins}

Saponins are secondary metabolites largely distributed in the plant kingdom and mainly found in seeds, leaves, roots, fruits and stems. They are produced for plant protection against harmful microorganisms, birds and insects [31]. Saponins contain sugar chains and a triterpenoid aglycone (sapogenin) in their structure and are classified according to the number of sugar chains as mono-, di-, and tridesmosidic. Quinoa's outer seed coat is rich in saponins, and thus, the content in bitter genotypes varies from 140 to $2300 \mathrm{mg} / 100 \mathrm{~g}$ dry weight while that of sweet genotypes is ranged from 20 to $40 \mathrm{mg} / 100 \mathrm{~g}$ dry weight $[32,33]$. Saponins from quinoa are a complex mixture of triterpene glycosides derived from oleanolic acid, hederagenin, phytolaccagenic acid, serjanic acid, and 3b,23,30-trihydroxyolean-12-en-28-oic acid, which bear hydroxyl and carboxylate groups at C-3 and C-28, respectively. The major carbohydrates are glucose, arabinose, and galactose, while glucuronic acid and xylose have been found in low quantity [34]. Although the majority of studies report around 20 saponins in quinoa [34, 35], Madl and coworkers identified, by nano-HPLC electrospray ionization multistage tandem mass spectrometry, 87 saponins in a complex triterpene saponin crude extract from quinoa seed coats [36]. The recent published quinoa genome has allowed the identification of the transcription factor involved in controlling the triterpenoid seed saponins synthesis [37]. This finding is expected to advance on the selection for sweet varieties of quinoa with low content of saponins.

Saponins are the most important anti-nutritional factors present in the seed coat of quinoa that interfere with its palatability and digestibility making their removal before seed consumption necessary. They are removed either by the wet method, i.e. washing and rubbing in cold water, or by dry method, i.e. toasting and subsequent rubbing of the grains to remove the outer layers [38].

In spite of their indigestible characteristics, a broad range of biological activities have been described for saponins, including antiviral, antimicrobial, antioxidant, anti-inflammatory, cytotoxic, analgesic, hypocholesterolemic, hypoglycemic, anti-thrombotic, diuretic, minerals and vitamins absorption modulatory, neuroprotective, and immunostimulatory activities [39]. First studies reported the inhibitory capacity of quinoa saponins against the growth of Candida 
Table 2. Biological activity of quinoa protein hydrolyzates and peptides

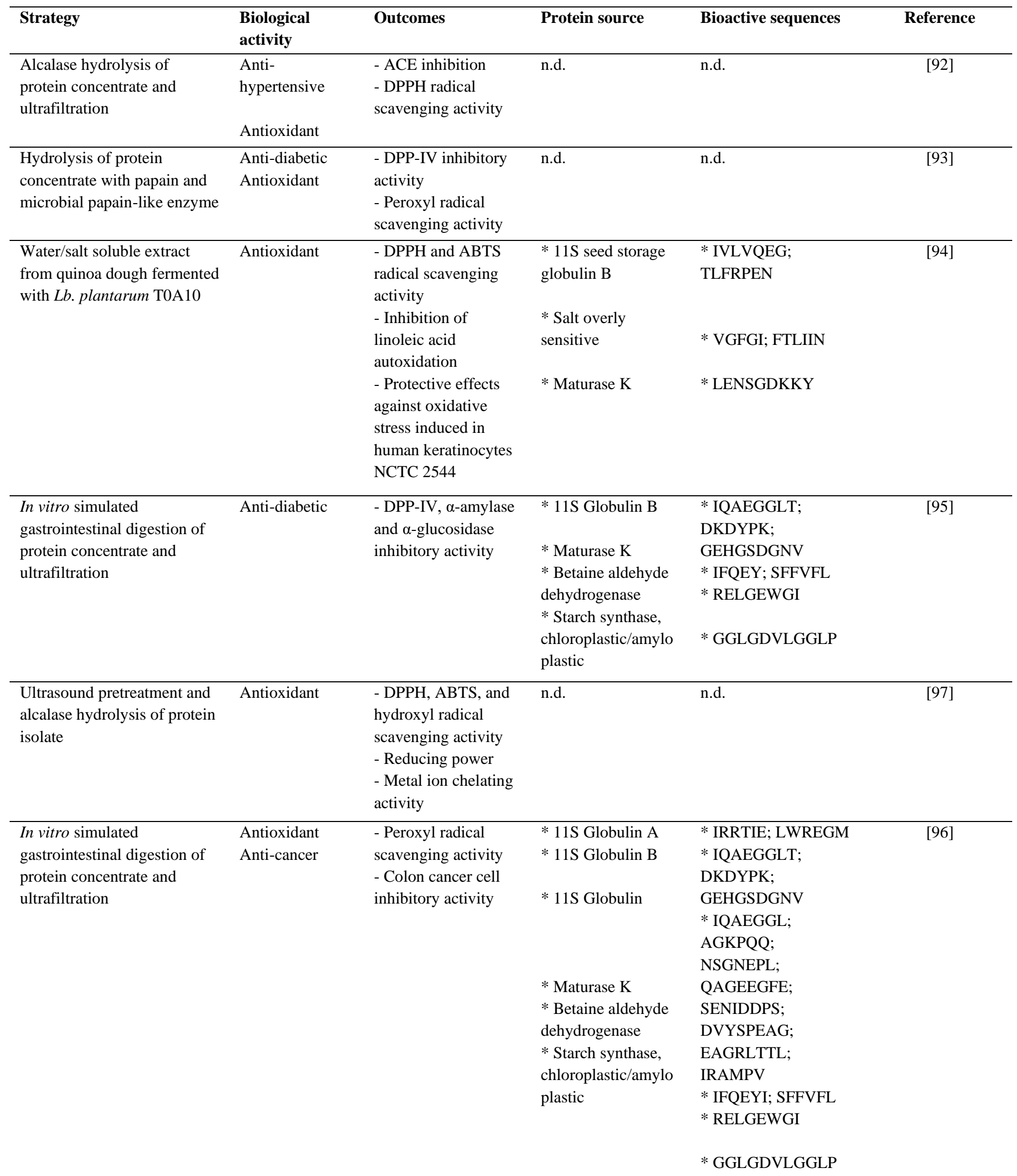


albicans [40] and Botrytis cinerea [41]. Last authors reported that alkali treatment of saponin extracts significantly increased the inhibitory capacity of mycelia growth and conidial germination. Quinoa bidesmosidic saponins and their aglycones have been found to exert cytotoxic effects through apoptosis induction in colon carcinoma Caco-2 cells [34]. Recently, Yao and coworkers demonstrated that saponin-rich quinoa seed extracts reduced the production of nitric oxide and the release of pro-inflammatory cytokines in lipopolysaccharide-stimulated RAW 264.7 macrophages [42]. Quinoa saponins were also able to suppress 3T3-L1 adipocytes differentiation and to decrease cell viability during the differentiation process [43]. These findings indicate that quinoa saponins are capable of suppressing adipogenesis, and therefore, they seem to be natural bioactive factors effective in adipose tissue mass modulation. Although the evidence on biological activities of quinoa saponins in animals is scarce, these compounds have demonstrated to enhance the production of humoral and cellular immune responses in mice subcutaneously immunized with ovalbumin [44].

\section{Phytosterols}

Phytosterols are triterpenes containing a 27-30-carbon ring-based structure with hydroxyl groups $[45,46]$. Their structure is similar to cholesterol found in animals and humans, making phytosterols compete for cholesterol's intestinal absorption and decrease atherogenic lipoprotein production in the intestines and liver, thus exerting reduction of serum cholesterol levels [47]. In addition to their cholesterol reducing properties, phytosterols have also demonstrated to exert antioxidant, anti-inflammatory, and anticancer effects [48]. The total phytosterols content reported in quinoa varies from 38.8 to $82.5 \mathrm{mg} / 100 \mathrm{~g}$ [48, 49], with $\beta$-sitosterol, campesterol, brassicasterol, and stigmasterol being the major components [50]. The quantities of these phytosterols are higher than those measured in barley, rye, millet, and corn [48].

\section{Phytoecdysteroids}

Phytoecdysteroids are polyhydroxylated steroids involved in plant defense against insects because of their structural relationship with molting hormones. In addition to their protection activity, phytoecdysteroids have demonstrated to improve keratinocyte differentiation [51], and to enhance dermal thickness and promote wound healing in vivo [52, 53]. Also, these compounds have been found to augment protein synthesis in skeletal muscle cells [54], and to reduce cobalt chloride and $\mathrm{H}_{2} \mathrm{O}_{2}$-induced production of reactive oxygen species (ROS) in rat pheochromocytoma PC12 and rat neuroblastoma B35 cells, respectively [55]. Quinoa is one of the richest edible sources of phytoecdysteroids, with a content ranged from 13.8 to $57.0 \mathrm{mg} / 100$ $\mathrm{g}$ dry weight [56]. Among 13 different types of phytoecdysteroid identified in quinoa, 20hydroxyecdysone $(20 \mathrm{HE})$ is the most abundant, constituting $62-90 \%$ of total quinoa phytoecdysteroids [56, 57]. Other minor phytoecdysteroids identified in quinoa are makisterone A, 24-epi-makisterone A, 24(28)-dehydromakisterone A and polypodine B, 24,25dehydroinokosterone, 25,27-dehydroinokosterone, and 5b-hydroxy-24(28)-dehydromakisterone A [56]. Administration of $20 \mathrm{HE}(10 \mathrm{mg} / \mathrm{kg}$ body weight for 13 weeks $)$ to diet-induced obese and hyperglycemic mice significantly reduced blood glucose levels, body weight and adiposity, and increased insulin sensitivity compared with the control mice, without affecting food consumption 
[58]. More recently, a 20HE-enriched quinoa extract has been found to prevent the onset of dietinduced obesity and to regulate the expression of adipocyte-specific genes in mice [59, 60]. This anti-obesity effect might be explained by a global augment in energy expenditure, a shift in glucose metabolism towards oxidation to the detriment of lipogenesis, and a reduction in lipid absorption leading to reduced dietary lipid storage in adipose tissue [61]. Currently, Graf and coworkers used the Caenorhabditis elegans model to demonstrate that treatment with a quinoa preparation enriched in 20HE improves lifespan, locomotory performance, basal respiration rate, and reduces advanced glycation end-product pigment and ROS accumulation [62]. This finding suggests that supplementation with 20HE-containing quinoa products may promote metabolic health in $C$. elegans through a conserved mechanism that might be extrapolated to humans.

\section{Phenolic compounds}

Phenolics are a large and diverse family of secondary plant metabolites with a highly stable chemical structure containing hydroxyl group(s) attached to at least one aromatic hydrocarbon ring. In general, phenolic compounds are divided into several groups, including phenolic acids, flavonoids, lignans, coumarins, phenols, phenylpropanoids, quinines, stilbenoids, and xanthones. The total polyphenol content determined in quinoa seeds was in the range between 0.46 and 1.84 $\mathrm{mg} / \mathrm{g}$ dry weight [63]. Flavonol glycosides represent the most abundant phenolics in this plant [64]. They are constituted mainly by quercetin and kaempferol derivatives, with concentrations of individual compounds around $0.84 \mathrm{mg} / \mathrm{g}$ dry weight $[65,66]$. According to Paśko et al. quinoa seeds contained flavonoids, mainly orientin $(1.08 \mathrm{mg} / \mathrm{g}$ dry weight $)$, vitexin $(0.71 \mathrm{mg} / \mathrm{g}$ dry weight), and rutin $(0.36 \mathrm{mg} / \mathrm{g}$ dry weight), but also morin $(88.9 \mu \mathrm{g} / \mathrm{g}$ dry weight), hesperidin $(1.86 \mu \mathrm{g} / \mathrm{g}$ dry weight), and neohesperidin (1.93 $\mu \mathrm{g} / \mathrm{g}$ dry weight) [67]. Individual phenolic acids such as ferulic, caffeic, and p-coumaric acids are present at concentrations of 251.5, 6.31, and 1.1 $\mu \mathrm{g} / \mathrm{g}$ dry weight, respectively [68]. Two recent studies have identified 23 and 19 phenolic compounds in either free or conjugated (liberated by alkaline and/or acid hydrolysis) forms in quinoa seed extracts $[69,70]$. They are mainly phenolic acids consisting of vanillic, ferulic, $\mathrm{p}$ coumaric, protocatechuic, 4-hydroxybenzoic, and 8,5'-diferulic acids and their derivatives, along with flavonoids quercetin, kaempferol and their glycosides. Ferulic acid-4-glucoside, present at concentrations ranged from 132-161 $\mu \mathrm{g} / \mathrm{g}$ dry weight was the predominant free phenolic compound, while vanillic acid and ferulic acid were the two dominant extractable phenolics in bound forms, at concentrations of $207-250 \mu \mathrm{g} / \mathrm{g}$ and $169-231 \mu \mathrm{g} / \mathrm{g}$ of quinoa seed, respectively. Lutz and others identified isoflavones in 10 different quinoa seed varieties, reporting concentrations of 0.5 to $4.1 \mu \mathrm{g}$ of genistein/g and 7.0 to $20.5 \mu \mathrm{g}$ of daidzein/100 $\mathrm{g}$ [71]. A tannin content of $0.05 \%$ has been determined for quinoa, whose value is comparable with that of amaranth and higher than that determined in rice $(0.035 \%)$ and soybean $(0.034 \%)$ [68].

The stable chemical structure of phenolic compounds confers them potent antioxidant properties exerted through different mechanisms. They act as reducers, have the ability to scavenge free radicals and chelate metal ions - cofactors of enzymes catalyzing oxidative reactions, inhibit oxidases, terminate radical chain reactions and/or stabilize free radicals [72]. A great number of studies have assessed the in vitro antioxidant activity of quinoa seeds in relation to their phenolic content and composition $[66,73]$ and compared to that of some legumes, 
cereals, and pseudocereals $[24,68,74]$. Although some recent studies have found a positively correlation between the free, bound, and total phenolic compounds contained in quinoa seeds and their antioxidant capacity [75], the contribution of non-phenolic compounds on this capacity has also been suggested $[69,76]$.

In addition to their antioxidant properties, phenolic compounds have been shown to exert other biological activities such as anti-inflammatory, anticancer, anti-diabetic, anti-obesity, and cardioprotective effects [39]. Quinoa polyphenols have been reported to down-regulate interleukin (IL)-1 $\beta$, IL-8, and tumor necrosis factor (TNF) cytokines in colonic epithelial Caco-2 cells, and to prevent obesity-induced inflammation and promote gastrointestinal health in mice [77]. Hemalatha and coworkers found that phenolics from whole grain quinoa and its milled fractions acted as potent antioxidants and inhibitors of $\alpha$-amylase and $\alpha$-glucosidase [78]. Inhibitory effects on $\alpha$-glucosidase and pancreatic lipase activities have also been described for bound phenolics identified in quinoa [70]. These findings suggest that quinoa phenolics may have the potential to prevent hyperglycaemia and its associated complications because their ability to slow both intestinal digestion of carbohydrates and oxidation-related damage [78].

\section{Polysaccharides}

Nowadays, polysaccharides from natural sources have gained interest due to their role as scavengers of free radicals, lipid oxidation inhibitory agents, promoters of natural killer cells, and macrophages and interleukins activators [79, 80]. Studies carried out in the last years have focused on the polysaccharides contained in the quinoa fiber fraction. Cordeiro et al. characterized a pool of arabinan and arabinan-rich pectic polysaccharides present in quinoa seeds which anti-ulcer effects in an ethanol-induced gastric damage rat model were also demonstrated [81]. Four polysaccharide sub-factions isolated and purified from quinoa showed significant antioxidant and immunoregulatory activities [82]. Recently, a novel polysaccharide fraction constituted by galacturonic acid and glucose has been identified [83]. The purified fraction exhibited significant radical scavenging and macrophage RAW264.7 proliferation promoting activities, while it suppressed the nitric oxide production on inflammatory RAW264.7 macrophages. Moreover, polysaccharide fraction displayed cytotoxic effects against human liver cancer SMMC 7721 and breast cancer MCF-7 cells, while no effects on normal cells were observed [83].

\section{Betalains}

Betalains are nitrogenous plant pigments that belong to the order Caryophyllales. According to their chemical structure, they can be subdivided into red-violet betacyanins or yellow-orange betaxanthins which combination makes the orange and red shades that coexist in nature. Extracts containing betalains have been approved as natural colorants in food products and pharmaceuticals by the European Union (additive E-162) and the US FDA [84]. Moreover, in recent years, betalains have gained popularity as ingredient of functional foods owing to their antioxidant, anticancer, anti-lipidemic and antimicrobial activities [85, 86]. Quinoa is considered a promising crop for the extraction of betalains although the results on their content in different quinoa varieties are controversial. Repo-Carrasco-Valencia et al. [87] did not detect the presence 
of betacyanins in some Peruvian Altiplano's red quinoa seeds while Abderrahim and coworkers [88] determined variable betalain contents $(0.15-6.10 \mathrm{mg} / 100 \mathrm{~g}$, expressed as the sum of betacyanins and betaxanthins) in coloured quinoa seeds from the same Peruvian zone. Tang and coworkers (2015) reported a similar betanin and isobetanin content in red and black quinoa cultivated in Canada than that found in beet root although quantitative data were not provided [69]. A recent study has allowed identifying novel betacyanins and betaxanthins in 29 Peruvian quinoa varieties, correlating their presence with the high antioxidant and free radical scavenging activities measured in grain extracts [89]. These authors suggest that colored quinoa seeds might be interesting as a natural source of bioactive betalains. To stabilize these compounds, microencapsulation has been recently studied [90]. Maltodextrin-microencapsulations containing betacyanin and low saponin concentration might confer unique health-promoting properties.

\section{Bioactive proteins and peptides}

In addition to their nutritional properties, quinoa proteins have been found to exert biological properties. A quinoa protein-enriched fraction was found to prevent the increase of total cholesterol levels in plasma and liver of mice through inhibition of the re-absorption of bile acids in the small intestine and control of cholesterol synthesis and catabolism [91]. Moreover, quinoa proteins have been currently recognized as a source of bioactive peptides although the studies are still scarce (Table 3). Aluko and Monu reported by the first time the antioxidant and angiotensin-converting enzyme inhibitory activities of a quinoa protein hydrolyzate obtained with alcalase [92]. Then, papain hydrolyzates from quinoa protein were also found to exert antioxidant and dipeptidyl peptidase IV (DPP-IV) inhibitory effects [93]. The results of this study presented quinoa protein as a promising functional ingredient with anti-diabetic properties although the peptide sequences responsible for the observed effects were not identified. In the last few years, peptides from different sequenced quinoa proteins have been identified in both fermented dough [94], and gastrointestinal digests [95, 96]. The multifunctional properties including antioxidant, anti-diabetic, and chemopreventive activities demonstrated for some of those peptides have made quinoa proteins gain importance as food ingredients for the prevention and/or management of chronic diseases related to oxidative stress, hypertension and/or diabetes. However, the bioavailability and mechanism of action of these peptides should be further explored to confirm their in vivo effects.

\section{Health benefits of quinoa}

In spite of many compounds contained in quinoa have been described to contribute on the beneficial effects on human health attributed to this pseudocereal, to date, the evidence on these benefits demonstrated in both animals and humans is still limited. Quinoa supplementation in the diet administered to oxidative stress-induced rats reduced malondialdehyde levels in plasma and increased antioxidant enzymes activities [98]. Another study of these authors demonstrated the ability of quinoa to reduce serum glucose, triglycerides (TG), and total and low density lipoproteins (LDL) cholesterol levels in male Wistar rats fed a fructose-enriched diet, inhibiting the negative effects of fructose on high density lipoproteins (HDL) [99]. These findings indicate the protective effects of quinoa against oxidative stress by increasing the antioxidant capacity 
and reducing the lipid peroxidation in plasma and tissues of animals. The preventive role of quinoa against obesity has been also investigated [100].

Table 3. Evidences on the effects of quinoa and derived products in humans

\begin{tabular}{|c|c|c|c|c|c|}
\hline Participants & $\begin{array}{c}\text { No. of } \\
\text { participants }\end{array}$ & Treatment & $\begin{array}{l}\text { Duration } \\
\text { (days) }\end{array}$ & Outcomes & Reference \\
\hline $\begin{array}{l}\text { 50-65-month- } \\
\text { old boys }\end{array}$ & 40 & $\begin{array}{l}200 \mathrm{~g} \text { quinoa- } \\
\text { porridge } \\
\text { beverage/day }\end{array}$ & 15 & Increase of IGF-1 & [19] \\
\hline $\begin{array}{l}18-45 \text { years old } \\
\text { students }\end{array}$ & 22 & Quinoa candies & 30 & $\begin{array}{l}\text { Reduction of TG, total and } \\
\text { LDL-cholesterol } \\
\text { Reduction (no significant) of } \\
\text { blood pressure, blood sugar } \\
\text { and body weight }\end{array}$ & {$[101]$} \\
\hline $\begin{array}{l}\text { Post- } \\
\text { menopausal } \\
\text { overweight } \\
\text { women }\end{array}$ & 35 & 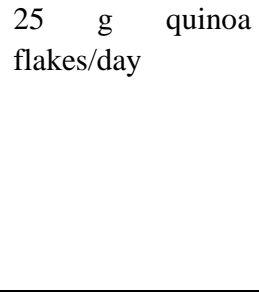 & 28 & $\begin{array}{l}\text { Reduction of TG, TBARS } \\
\text { and vitamin E levels } \\
\text { Increase of urinary secretion } \\
\text { of enterolignans } \\
\text { Decrease of total and LDL- } \\
\text { cholesterol } \\
\text { Increase of GSH }\end{array}$ & [102] \\
\hline $\begin{array}{l}\text { Overweight and } \\
\text { obese adults }\end{array}$ & 50 & $50 \mathrm{~g}$ quinoa/day & 84 & $\begin{array}{l}\text { Reduction of TG } \\
\text { Reduction of prevalence of } \\
\text { metabolic syndrome }\end{array}$ & [103] \\
\hline $\begin{array}{l}\text { Overweight } \\
\text { men }\end{array}$ & 37 & $\begin{array}{l}\text { Quinoa-enriched } \\
\text { bread ( } 20 \mathrm{~g} \text { quinoa } \\
\text { flour)/day }\end{array}$ & 28 & $\begin{array}{l}\text { Reduction of blood pressure } \\
\text { and LDL-cholesterol }\end{array}$ & [104] \\
\hline $\begin{array}{ll}\text { Adult } & \text { celiac } \\
\text { patients } & \end{array}$ & 19 & $50 \mathrm{~g}$ quinoa/day & 42 & $\begin{array}{l}\text { Improvement of histological } \\
\text { parameters } \\
\text { Reduction of total, LDL, and } \\
\text { HDL cholesterol, and TG }\end{array}$ & [105] \\
\hline Healthy adults & 12 & Quinoa "risotto" & & $\begin{array}{ll}\text { Increase of satiating } \\
\text { efficiency indices }\end{array}$ & [106] \\
\hline $\begin{array}{l}\text { Pre-diabetic } \\
\text { individuals }\end{array}$ & 30 & $\begin{array}{l}\text { Commercial } \\
\text { quinoa flour }(20 \mathrm{~g} \\
\text { quinoa)/day }\end{array}$ & 28 & $\begin{array}{l}\text { Reduction of IMC and } \\
\text { glycated hemoglobin } \\
\text { Increase in the satiation and } \\
\text { fullness (complete) degree }\end{array}$ & [107] \\
\hline Healthy adults & 30 & \begin{tabular}{lr}
\multicolumn{2}{l}{ Macaroni and } \\
cheese dish \\
prepared with \\
quinoa flour & \\
\end{tabular} & --- & $\begin{array}{l}\text { Increase of the peak } \\
\text { glycemic response following } \\
\text { meal ingestion }\end{array}$ & [108] \\
\hline
\end{tabular}

These authors showed that administration of 20HE-enriched quinoa extract to mice fed a high fat diet for 3 weeks resulted in the reduction of the development of adipose tissue without changes in body weight gain. This adipose tissue-specific effect was associated to the down-regulation of expression of genes involved in lipid storage.

To date, a reduced number of human trials have been conducted to evaluate the benefits of quinoa consumption (Table 3). Administration, twice a day, of $100 \mathrm{~g}$ quinoa to 50-65 month old boys in low-income families in Ecuador for 15 days significantly augmented the plasma insulinlike growth factor (IGF-1) levels, when compared to the control group. Thus, it was indicated that quinoa-enriched baby food provided sufficient protein and other essential nutritional 
elements capable to prevent child malnutrition [19]. Moreover, supplementation of diet with quinoa has been demonstrated to modulate cardiovascular and metabolic parameters in both healthy [101] and overweight and obese individuals [102-104]. In order to evaluate the safety of its consumption, quinoa was administered to celiac patients as a gluten-free alternative to cereal grains [105]. This study reported an improvement in histological and gastrointestinal parameters and reduction in TG, and total, LDL, and HDL cholesterol after consumption of $50 \mathrm{~g}$ quinoa/day for 6 weeks.

\section{CONCLUSIONS}

Quinoa is a traditionally important and environmental stress-tolerant pseudocereal with high nutritional value. One serving of quinoa (about $40 \mathrm{~g}$ ) has been reported to meet a significant part of daily recommendations for essential nutrients, mainly amino acids, vitamins, and minerals. Therefore, its potential to provide nutrition to millions of malnourished people worldwide has been recognized. Moreover, quinoa is gluten-free, and thus, it is generally safe for people with celiac disease. Apart from having excellent nutritional profile, quinoa contains a plethora of bioactive compounds including saponins, phytosterols, phytoecdysteroids, phenolic compounds, polysaccharides, and bioactive proteins and peptides. These compounds exert positive effects on different body systems helping to promote human health and to reduce risk of different chronic disorders including cancer, cardiovascular diseases, diabetes, and aging. However, to data, the available evidence on these health benefits is still limited, making need for further studies, including animal assays and human trials that allow confirming quinoa's properties, emphasizing on the phytochemicals' mechanisms of action, bioavailability, and interactions. The development of new functional foods that integrates quinoa in modern diets should be also of great value to improve public nutrition and health using traditional agricultural resources more efficiently.

List of abbreviations: DPP-IV: dipeptidyl peptidase IV; FAO: Food and Agriculture Organization; HDL: high density lipoproteins; IGF-1: insulin-like growth factor-1; IL: interleukin; LDL: low density lipoproteins; ROS: reactive oxygen species; TG: triglycerides; TNF: tumor necrosis factor; 20HE: 20-hydroxyecdysone.

Acknowledgments: This work has received financial support from project AGL2015-66886-R (Spanish Ministry of Economy and Competitiveness, MINECO, Spain).

Conflicts of Interest: Author declares no conflicts of interest.

Authors' Contributions: Blanca Hernández-Ledesma conceived the idea of the manuscript and wrote it.

\section{REFERENCES}

1. Tapia M: Cultivos andinos subexplotados y su aporte a la alimentación (2nd ed). FAO, Oficina Regional para América Latina y el Caribe, Santiago, Chile; 1997.

2. Bonifacio A: Chenopodium sp.: Genetic resources, ethnobotany, and geographic distribution. Food Rev Int 2003, 19: 1-7. 
3. Jacobsen SE: The worldwide potential for quinoa (Chenopodium quinoa Willd.). Food Rev Int 2003, 19: 167-177.

4. Jacobsen SE: The situation for quinoa and its production in Southern Bolivia: from economic success to environmental disaster. J Agron Crop Sci 2011, 197: 390-399.

5. Gonzalez JA, Konishi Y, Bruno M, Valoy M, Prado FE: Interrelationships among seed yield, total protein and amino acid composition of ten quinoa (Chenopodium quinoa) cultivars from two different agroecological regions. J Sci Food Agric 2012, 92: 12221229.

6. Food and Agriculture Organization of the United Nations, Statistic Division (FAOSTAT) [http://www.fao.org/faostat/en/\#data/QC/visualize]; 2018.

7. Bhargava A, Shukla S, Ohri D: Chenopodium quinoa - An Indian perspective. Ind Crops Prod 2006, 23: 73-87.

8. FAO: Quinoa: an ancient crop to contribute to world food security. Santiago de Chile: FAO Regional Office for Latin America and the Caribbean; 2011.

9. Oelke EA, Putnam DH, Teynor TM, Oplinger ES: Alternative field crops manual. University of Wisconsin Cooperative Extension Service, University of Minnesota Extension Service, Centre for Alternative Plant and Animal Products; 1992.

10. Schlick G, Bubenheim DL: Quinoa: Candidate crop for NASA's controlled ecological life support systems. In Progress in new crops. Edited by Janick J. ASHS Press, Alexandria, VA, USA; 1996: 632-640.

11. Vega-Galvez A, Miranda M, Vergara J, Uribe E, Puente L, Martínez EA: Nutrition facts and functional potential of quinoa (Chenopodium quinoa Willd.), an ancient Andean grain: a review. J Sci Food Agric 2010, 90: 2541-2547.

12. Konishi Y: Nutritional characteristics of pseudocereal amaranth and quinoa: alternative foodstuff for patients with food allergy. J Jpn Soc Nutr Food Sci 2002, 55: 299-302.

13. USDA: United States Department of Agriculture. National Nutrient Database for Standard Reference Release, 2018.

14. Navruz-Varli S, Sanlier N: Nutritional and health benefits of quinoa (Chenopodium quinoa Willd.). J Cereal Sci 2016, 69: 371-376.

15. Abugoch James LE: Quinoa (Chenopodium quinoa Willd.): composition, chemistry, nutritional, and functional properties. Adv Food Nutr Res 2009, 58: 1-31.

16. WHO (Eds): Protein and amino acid requirements in human nutrition. WHO Technical Report Series 935; 2007.

17. Dini I, Tenore GD, Dini A: Nutritional and antinutritional composition of Kancolla seeds: an interesting and underexploited andine food plant. Food Chem 2005, 92: 125-132.

18. Comai S, Bertazzo A, Bailoni L, Zancato M, Costa C, Allegri G: The content of proteic and nonproteic (free and protein-bound) tryptophan in quinoa and cereal flours. Food Chem 2007, 100: 1350-1355.

19. Ruales J, De Grijalva Y, Lopez-Jaramillo P, Nair BM: The nutritional quality of infant food from quinoa and its effect on the plasma level of insulin-like growth factor-1 (IGF-1) in undernourished children. Int J Food Sci Nutr 2002, 53: 143-154.

20. Repo-Carrasco R, Espinoza C, Jacobsen SE: Nutritional value and use of the andean crops quinoa (Chenopodium quinoa) and kañiwa (Chenopodium pallidicaule). Food Rev Int 2003, 19: 179-189. 
21. Lamothe LM, Srichuwong S, Reuhs BL, Hamaker BR: Quinoa (Chenopodium quinoa W.) and amaranth (Amaranthus caudatus L.) provide dietary fibres high in pectic substances and xyloglucans. Food Chem 2015, 167: 490-496.

22. Przybylski R, Chauhan G, Eskin N: Characterization of quinoa (Chenopodium quinoa) lipid. Food Chem 1994, 51: 187-192.

23. Maradini Filho AM, Ribeiro Pirozi M, Da Silva Borges JT, Pinheiro Sant'Ana HM, Paes Chaves JB, Dos Reis Coimbra JS: Quinoa: Nutritional, functional, and antinutritional aspects, Crit Rev Food Sci Nutr 2017, 57: 1618-1630.

24. Alvarez-Jubete L, Arendt EK, Gallagher E: Polyphenol composition and in vitro antioxidant activity of amaranth, quinoa buckwheat and wheat as affected by sprouting and baking. Food Chem 2010, 119: 770-778.

25. Craig SA: Betaine in human nutrition. Am J Clin Nutr 2004, 80: 539-548.

26. Zeisel SH, Caudill MA: Choline. Adv Nutr 2010, 1: 46-48.

27. Filipcev B, Kojic J, Krulj J, Bodroza-Solarov M, Ilic N: Betaine in cereal grains and grainbased products. Foods 2018, 7: 49.

28. Bruce SJ, Guy PA, Rezzi S, Ross AB: Quantitative measurement of betaine and free choline in plasma, cereals and cereal products by isotope dilution LC-MS/MS. J Agric Food Chem 2010, 58: 2055-2061.

29. Ross AB, Zangger A, Guiraud SP: Cereal foods are the major source of betaine in the Western diet-Analysis of betaine and free choline in cereal foods and updated assessments of betaine intake. Food Chem 2014, 145: 859-865.

30. National Academy of Sciences: Comprehensive DRI table for vitamins, minerals and macronutrients, organized by age and gender. Institute of Medicine. Food and Nutrition Board, Beltsville, MD, 2004.

31. Singh B, Kaur A: Control of insect pests in crop plants and stored food grains using plant saponins: a review. J Food Sci Technol 2018, 87: 93-101.

32. Mastebroek D, Limburg H, Gilles T, Marvin H: Occurrence of sapogenins in leaves and seeds of quinoa (Chenopodium quinoa Willd.). J Sci Food Agric 2000, 80: 152-156.

33. Guclu-Ustundag O, Mazza G: Saponins: Properties, applications and processing. Crit Rev Food Sci Nutr 2007, 47: 231-258.

34. Kuljanabhagavad T, Thongphasuk P, Chamulitrat W, Wink M: Triterpene saponins from Chenopodium quinoa Willd. Phytochem 2008, 69: 1919-1926.

35. Ruiz KB, Khakimov B, Engelsen SB, Bak S, Biondia S, Jacobsen S-E: Quinoa seed coats as an expanding and sustainable source of bioactive compounds: An investigation of genotypic diversity in saponin profiles. Ind Crops Prod 2017, 104: 156-163.

36. Madl T, Sterk H, Mittelbach M: Tandem Mass spectrometric analysis of a complex triterpene saponin mixture of Chenopodium quinoa. Am Soc Mass Spectrom 2006, 17: 795-806.

37. Jarvis DE, Ho YS, Lightfoot DJ, Schmockel SM, Li B, Borm TJA, Ohyanagi H, et al.: The genome of Chenopodium quinoa. Nature 2017, 542: 307-312.

38. Risi J, Galwey NW: Genotype $\times$ environment interaction in the Andean grain crop quinoa (Chenopodium quinoa) in temperate environments. Plant Breed 1991, 107: 141-147. 
39. Graf BL, Rojas-Silva P, Rojo LE, Delatorre-Herrera J, Baldeon ME, Raskin I: Innovations in health value and functional food development of quinoa (Chenopodium quinoa Willd.). Comp Rev Food Sci Food Safety 2015, 14: 431-445.

40. Woldemichael GM, Wink M: Identification and biological activities of triterpenoid saponins from Chenopodium quinoa. J Agric Food Chem 2001, 49: 2327-2332.

41. Stuardo M, San Martin R: Antifungal properties of quinoa (Chenopodium quinoa Willd) alkali treated saponins against Botrytis cinerea. Ind Crops Prod 2008, 27: 296-302.

42. Yao Y, Yang X, Shi Z, Ren G: Anti-inflammatory activity of saponins from quinoa (Chenopodium quinoa Willd.) seeds in lipopolysaccharide-stimulated RAW 264.7 macrophages cells. J Food Sci 2014, 79: H1018-H1023.

43. Yao Y, Zhu Y, Gao Y, Shi Z, Hua Y, Ren G: Suppressive effects of saponin-enriched extracts from quinoa on 3T3-L1 adipocyte differentiation. Food Funct 2015, 6: 32823290.

44. Verza SG, Silveira F, Cibulski S, Kaiser S, Ferreira F, Gosmann G, Roehe PM, et al.: Immunoadjuvant activity, toxicity assays, and determination by UPLC/Q-TOF-MS of triterpenic saponins from Chenopodium quinoa seeds. J Agric Food Chem 2012, 60: 31133118.

45. Piironen V, Toivo J, Lampi A: Natural sources of dietary plant sterols. J Food Comp Anal 2000, 13: 619-624.

46. MacKay DS, Jones PJH: Phytosterols in human nutrition: type, formulation, delivery, and physiological function. Eur J Lipid Sci Tech 2011, 113: 1427-1432.

47. Ho SS, Pal S: Margarine phytosterols decrease the secretion of atherogenic lipoproteins from HepG2 liver and Caco2 intestinal cells. Atherosclerosis 2005, 182:29-48. Ryan E, Galvin K, O’Connor TP, Maguire AR, O’Brien NM: Phytosterol, squalene, tocopherol content and fatty acid profile of selected seeds, grains, and legumes. Plant Food Hum Nutr 2007, 62: 85-91.

48. Islam MA, Jeong B-G, Jung J, Shin E-C, Choi S-G, Chun J: Phytosterol determination and method validation for selected nuts and seeds. Food Anal Methods 2017, 10: 3225-3234.

49. Villacr'es E, P'astor G, Quelal MB, Zambrano I, Morales SH: Effect of processing on the content of fatty acids, tocopherols and sterols in the oils of quinoa (Chenopodium quinoa Willd), lupine (Lupinus mutablis Sweet), amaranth (Amaranthus caudatus L.) and sangorache (Amaranthus quitensis L.). Glob J Food Sci Technol 2013, 2: 44-53.

50. Detmar M, Dumas M, Bonte F, Meybeck A, Orfanos CE: Effects of ecdysterone on the differentiation of normal human keratinocytes in-vitro. Eur J Dermatol 1994, 4: 558-562.

51. Zhegn GY, Wu X, Li YL, Zhang JH, Wang WJ: Preparation and dose-effect analysis of ecdysterone cream for promoting wound healing. Nan Fang Yi Ke Da Xue Xue Bao 2008, 28: 828-831.

52. Ehrhardt C, Wessels JT, Wuttke W Seidlova-Wuttke D: The effects of 20hydroxyecdysone and 17ß-estradiol on the skin of ovariectomized rats. Menopause 2011, 18: 323-327.

53. Gorelick-Feldman J, Cohick W, Raskin I: Ecdysteroids elicit a rapid $\mathrm{Ca}^{2+}$ flux leading to Akt activation and increased protein synthesis in skeletal muscle cells. Steroids 2010, 75 : 632-637. 
54. Hu J, Luo CX, Chu WH, Shan YA, Qian Z-M, Zhu G, Yu YB, et al.: 20Hydroxyecdysone protects against oxidative stress-induced neuronal injury by scavenging free radicals and modulating NF-jB and JNK pathways. PLoS One 2012, 7: e50764.

55. Graf B, Rojo LE, Delatorre-Herrera J, Poulev A, Calfio C, Raskin I: Phytoecdysteroids and flavonoid glycosides among Chilean and commercial sources of Chenopodium quinoa: variation and correlation to physicochemical characteristics. J Sci Food Agric 2016, 96: 633-643.

56. Kumpun S, Maria A, Crouzet S, Evrard-Todeschi N, Girault J-P, Lafont R: Ecdysteroids from Chenopodium quinoa Willd., an ancient Andean crop of high nutritional value. Food Chem 2011, 125: 1226-1234.

57. Kizelsztein P, Govorko D, Komarnytsky S, Evans A, Wang Z, Cefalu WT, Raskin I: 20Hydroxyecdysone decreases weight and hyperglycemia in a diet-induced obesity mice model. Am J Physiol Endocrinol Metab 2009, 296: E433-E439.

58. Foucault A-S, Mate V, Lafont R, Even P, Dioh W, Veillet S, Tome D, et al.: Quinoa extract enriched in 20-Hydroxyecdysone protects mice from diet-induced obesity and modulates adipokines expression. Obesity 2011, 20: 270-277.

59. Graf BL, Poulev A, Kuhn P, Grace M, Lila MA, Raskin I: Quinoa seeds leach phytochemicals and other compounds with anti-diabetic properties. Food Chem 2014, 163: 178-185.

60. Foucault A-S, Even P, Lafont R, Dioh W, Veillet S, Tome D, Huneau J-F, et al.: Quinoa extract enriched in 20-hydroxyecdysone affects energy homeostasis and intestinal fat absorption in mice fed a high-fat diet. Physiol Behav 2014, 128: 226-231.

61. Graf BL, Kamat S, Cheong KY, Komarnytsky S, Driscoll M, Di R: Phytoecdysteroidenriched quinoa seed leachate enhances health span and mitochondrial metabolism in Caenorhabditis elegans. J Funct Foods 2017, 37: 1-7.

62. Vollmannova E, Margianova E, Toth, T, Timoracka M, Urminska D, Bohnanska T, Cicova I: Cultivar influence on total polyphenol and rutin contents and total antioxidant capacity in buckwheat, amaranth, and quinoa seeds. Czech J Food Sci 2013, 31: 589-595.

63. Gomez-Caravaca AM, Segura-Carretero A, Fernandez-Gutierrez A, Caboni MF: Simultaneous determination of phenolic compounds and saponins in quinoa (Chenopodium quinoa Willd) by a liquid chromatography-diode array detectionelectrospray ionization-time-of-flight mass spectrometry methodology. J Agric Food Chem 2011, 59: 10815-10825.

64. Dini I, Tenore GC, Dini A: Phenolic constituents of Kancolla seeds. Food Chem 2004, 84: 163-168.

65. Hirose Y, Fujita T, Ishii T, Ueno N: Antioxidative properties and flavonoid composition of Chenopodium quinoa seeds cultivated in Japan. Food Chem 2010, 119: 1300-1306.

66. Pasko P, Sajewicz M, Gorinstein S, Zachwieja Z: Analysis of selected phenolic acids and flavonoids in Amaranthus cruentus and Chemopodium quinoa seeds and sprouts by HPLC. Acta Chromat 2008, 20: 661-672.

67. Gorinstein S, Lojek A, C1z M, Pawelzik E, Delgado-Licon E, Medina OJ, Moreno M, et al.: Comparison of composition and antioxidant capacity of some cereals and pseudocereals. Int J Food Sci Tech 2008, 43: 629-637. 
68. Tang Y, Li X, Zhang B, Chen PX, Liu R, Tsao R: Characterisation of phenolics, betanins and antioxidant activities in seeds of three Chenopodium quinoa Willd. genotypes. Food Chem 2015, 166: 380-388.

69. Tang Y, Zhang B, Li X, Chen PX, Zhang H, Liu R, Tsao R: Bound phenolics of quinoa seeds released by acid, alkaline, and enzymatic treatments and their antioxidant and $\alpha-$ glucosidase and pancreatic lipase inhibitory effects. J Agric Food Chem 2016, 64: 17121719.

70. Lutz M, Martinez A, Martinez EA: Daidzein and genistein contents in seeds of quinoa (Chenopodium quinoa Willd.) from local ecotypes grown in arid Chile. Ind Crops Prod 2013, 49: 117-121.

71. Rice-Evans CA, Miller NJ, Paganga G: Antioxidant properties of phenolic compounds. Trends Plant Sci 1997, 2: 152-159.

72. Dini I, Tenore GC, Dini A: Antioxidant compound contents and antioxidant activity before and after cooking in sweet and bitter Chenopodium quinoa seeds. Food Sci Technol 2010, 43: 447-451.

73. Laus MN, Gagliardi A, Soccio M, Flagella Z, Pastore D: Antioxidant activity of free and bound compounds in quinoa (Chenopodium quinoa Willd.) seeds in comparison with durum wheat and emmer. J Food Sci 2012, 77: C1150-C1155.

74. Abderrahim F, Huanatico E, Segura R, Arribas S, Gonzalez MC, Condezo-Hoyos L: Physical features, phenolic compounds, betalains and total antioxidant capacity of coloured quinoa seeds (Chenopodium quinoa Willd.) from Peruvian Altiplano. Food Chem 2015, 183: 83-90.

75. Nsimba RY, Kikuzaki H, Konishi Y: Antioxidant activity of various extracts and fractions of Chenopodium quinoa and Amaranthus spp. seeds. Food Chem 2008, 106: 760-766.

76. Noratto G, Carrion-Rabanal R, Medina G, Mencia A, Mohanty I, Gonzalez D, Murphy K: Quinoa protective effects against obesity-induced intestinal inflammation. FASEB J. 2015, 29: Supplement 602.9.

77. Hemalatha P, Bomzan DP, Sathyendra Rao BV, Sreerama YN: Distribution of phenolic antioxidants in whole and milled fractions of quinoa and their inhibitory effects on $\alpha$ amylase and $\alpha$-glucosidase activities. Food Chem 2016, 199: 330-338.

78. Yang XB, Zhao Y, Lv Y: In vivo macrophage activation and physicochemical property of the different polysaccharide fractions purified from Angelica sinensis. Carbohydr Polym 2008, 71: 372-379.

79. Song HF, Zhang QB, Zhang ZS, Wang J: In vitro antioxidant activity of polysaccharides extracted from Bryopsis plumosa. Carbohydr Polym 2010, 80: 1057-1061.

80. Cordeiro LMC, Reinhardt VD, Baggio CH, Werner MFD, Burci LM, Sassaki GL, Iacomini $\mathrm{M}$ : Arabinan and arabinan-rich pectic polysaccharides from quinoa (Chenopodium quinoa) seeds, Structure and gastroprotective activity. Food Chem 2012, 130: 937-944.

81. Yao Y, Shi Z, Ren G: Antioxidant and immunoregulatory activity of polysaccharides from quinoa (Chenopodium quinoa Willd.). Int J Mol Sci 2014, 15: 19307-19318.

82. Hu Y, Zhang J, Zou L, Fu C, Li P, Zhao G: Chemical characterization, antioxidant, immune-regulating and anticancer activities of a novel bioactive polysaccharide from Chenopodium quinoa seeds. Int J Biol Macromol 2017, 99: 622-629. 
83. Esatbeyoglu T, Wagner AE, Motafakkerazad R, Nakajima Y, Matsugo S, Rimbach, R: Free radical scavenging and antioxidant activity of betanin: electron spin resonance spectroscopy studies and studies in cultured cells. Food Chem Toxicol 2014, 73: 119-126.

84. Gengatharan A, Dykes GA, Choo WS: Betalains: natural plant pigments with potential application in functional foods. LWT - Food Sci Technol 2015, 64:645-649.

85. Gandia-Herrero F, Escribano J, Garcia-Carmona F: Biological activities of plant pigments betalains. Crit Rev Food Sci Nutr 2016, 56: 937-945.

86. Repo-Carrasco-Valencia R, Hellstrom JK, Pihlava J-M, Mattila PH: Flavonoids and other phenolic compounds in Andean indigenous grains: Quinoa (Chenopodium quinoa), kaniwa (Chenopodium pallidicaule) and kiwicha (Amaranthus caudatus). Food Chem 2010, 120: 128-133.

87. Abderrahim F, Huanatico E, Segura R, Arribas S, Gonzalez MC, Condezo-Hoyos L: Physical features, phenolic compounds, betalains and total antioxidant capacity of coloured quinoa seeds (Chenopodium quinoa Willd.) from Peruvian Altiplano. Food Chem 2015, 183: 83-90.

88. Escribano J, Cabanes J, Jimenez-Atienzar M, Ibanez-Tremolada M, Rayda Gomez-Pando L, Garcia-Carmona F, Gandia-Herrero F: Characterization of betalains, saponins and antioxidant power in differently colored quinoa (Chenopodium quinoa) varieties. Food Chem 2017, 234: 285-294.

89. Aguilar-Tuesta S, Mamani-Navarro W, Espinoza-Silva C, Basilio-Atencio J, CondezoHoyos L: Microencapsulated betacyanin from colored organic quinoa (Chenopodium quinoa Willd.): optimization, physicochemical characterization and accelerated storage stability. J Sci Food Agric 2018, 98: 5873-5883.

90. Takao T, Watanabe N, Yuhara K, Itoh S, Suda S, Tsuruoka Y, Nakatsugawa K, et al.: Hypocholesterolemic effect of protein isolated from quinoa (Chenopodium quinoa Willd.) seeds. Food Sci Technol Res 2005, 11: 161-167.

91. Aluko RE, Monu E: Functional and bioactive properties of quinoa seed protein hydrolysates. Food Chem Toxicol 2003, 68: 1254-1258.

92. Nongonierma AB, Le Maux S, Dubrulle C, Barre C, FitzGerald RJ: Quinoa (Chenopodium quinoa Willd.) protein hydrolysates with in vitro dipeptidyl peptidase IV (DPP-IV) inhibitory and antioxidant properties. J Cereal Sci 2015, 65: 112-118.

93. Rizzello CG, Lorusso A, Russo V, Pinto D, Marzani B, Gobbetti M: Improving the antioxidant properties of quinoa flour through fermentation with selected autochthonous lactic acid bacteria. Int J Food Microbiol 2017, 241: 252-261.

94. Vilcacundo R, Martinez-Villaluenga C, Hernandez-Ledesma B: Release of dipeptidyl peptidase IV, $\alpha$-amylase and $\alpha$-glucosidase inhibitory peptides from quinoa (Chenopodium quinoa Willd.) during in vitro simulated gastrointestinal digestion. J Funct Foods 2017, 35: 531-539.

95. Vilcacundo R, Miralles B, Carrillo W, Hernandez-Ledesma B: In vitro chemopreventive properties of peptides released from quinoa (Chenopodium quinoa Willd.) protein under simulated gastrointestinal digestion. Food Res Int 2018, 105: 403-411.

96. Li X, Da S, Li C, Xue F, Zang T: Effects of high-intensity ultrasound pretreatment with different levels of power output on the antioxidant properties of alcalase hydrolyzates 
from Quinoa (Chenopodium quinoa Willd.) protein isolate. Cereal Chem 2018, 95: 518526.

97. Pasko P, Barton H, Zagrodzki P, Izewska A, Krosniak M, Gawlik M, Gawlik M, et al.: Effect of diet supplemented with quinoa seeds on oxidative status in plasma and selected tissues of high fructose-fed rats. Plant Foods Hum Nutr 2010, 65: 146-151.

98. Pasko P, Zagrodzki P, Barton H, Chlopicka J, Gorinstein S: Effect of quinoa seeds (Chenopodium quinoa) in diet on some biochemical parameters and essential elements in blood of high fructose-fed rats. Plant Foods Hum Nutr 2010, 65: 333-338.

99. Foucault AS, Mathe V, Lafont R, Even P, DiohW, Veillet S, Tome D, et al.: Quinoa extract enriched in 20-hydroxyecdysone protects mice from diet induced obesity and modulates adipokines expression. Obesity 2011, 20: 270-277.

100. Farinazzi-Machado FMV, Barbalho SM, Oshiiwa M, Goulart R, Pessan Junior O: Use of cereal bars with quinoa (Chenopodium quinoa W.) to reduce risk factors related to cardiovascular diseases. Cienc Technol Aliment Campinas 2012, 32: 239-244.

101. De Carvalho FG, Ovidio PP, Padovan GJ, Jordao Junior AA, Marchini JS, Navarro AM: Metabolic parameters of postmenopausal women after quinoa or corn flakes intake-a prospective and double-blind study. Int J Food Sci Nutr 2014, 65: 380-385.

102. Navarro-Perez D, Radcliffe J, Tierney A, Jois M: Quinoa seed lowers serum triglycerides in overweight and obese subjects: a dose-response randomized controlled clinical trial. Curr Dev Nutr 2017, 1: e001321.

103. Li L, Lietz G, Bal W, Watson A, Morfey B, Seal C: Effects of quinoa (Chenopodium quinoa Willd.) consumption on markers of CVD risk. Nutrients 2018, 10: 777.

104. Zevallos VF, Herencia LI, Chang F, Donnelly S, Ellis HJ, Ciclitira PJ: Gastrointestinal effects of eating quinoa (Chenopodium quinoa Willd.) in celiac patients. Am J Gastroenterol 2014, 109: 270-278.

105. Berti C, Riso P, Brusamolino A, Porrini M: Effect on appetite control of minor cereal and pseudocereal products. Brit J Nutr 2005, 94: 850-858.

106. Abellan Ruiz MS, Barnuevo Espinosa MD, Garcia Santamaría C, Contreras Fernandez CJ, Aldeguer Garcia M, Soto Mendez F, Guillen Guillen I, et al.: Effect of quinua (Chenopodium quinoa) consumption as a coadjuvant in nutritional intervention in prediabetic subjects. Nutr Hosp 2017, 34: 1163-1169.

107. Johnston CS, Snyder D, Smith C: Commercially available gluten-free pastas elevate postprandial glycemia in comparison to conventional wheat pasta in healthy adults: a double-blind randomized crossover trial. Food Funct 2017, 8: 3139-3144. 